\title{
Effect of some degossypolisation treatments of cottonseed meal on its functional properties
}

\author{
By S.S. Mohamed \\ Fats and Oils Department, National Research Centre, Dokki, Cairo, Egypt.
}

\section{RESUMEN}

Efecto de algunos tratamientos de desgosiposilación de harina de semilla de algodón sobre sus propiedades funcionales.

La presencia de gosipol es un factor limitante en el uso de harina de semilla de algodón para la alimentación animal y humana. El gosipol, en forma libre, ha sido encontrado tóxico para animales monogástricos, y el Grupo Asesor en Proteína de Naciones Unidas ha limitado su contenido en productos proteínicos de semilla de algodón al 0,06\%. En el presente trabajo se ha estudiado el efecto de algunas técnicas de desgosiposilación sobre las propiedades funcionales de harinas de semillas de algodón. Los mejores resultados se obtuvieron con el método del ácido acético ya que mejoró la solubilidad de nitrógeno y lisina disponible, redujo el gosipol libre al $0,03 \%$ y aumentó la capacidad de absorción de agua, humectabilidad y fluidez. El producto proteínico resultante de este tratamiento puede ser incorporado en productos alimenticios instantáneos y horneados. El tratamiento azeótropo:amonio produjo efectos similares. El tratamiento con etanolamina está recomendado para la preparación de productos proteínicos para alimentos instantáneos.

PALABRAS-CLAVE: Gosipol (eliminación) - Harina - Propiedades funcionales - Semilla de algodón.

\section{SUMMARY}

Effect of some degossypolisation treatments of cottonsed meal on its functional properties.

The presence of gossypol is a limiting factor in the use of cottonseed meal for animal feed and human foods. Gossypol in the free form has been found to be toxic to monogastric animals and the Protein Advisor Group of U.N. has limited its content in cottonseed protein products to $0,06 \%$. In the present paper the effect of some degossypolisation techniques on the functional properties of cottonseed meals has been studied. Best results were obtained with the acetic acid method as it improved the nitrogen solubility and available lysine, reduced the free gossypol to $0,03 \%$ and enhanced the water absorption capacity, wettability and flowability. The protein product resulting from this treatment can be incorporated into bakery and instant products. The azeotrope: ammonium treatment produced similar effects. Ethanolamine treatment is recommended for the preparation of protein products for instant foods.

KEY-WORDS: Cottonseed - Functional properties - Gossypol (elimination) - Meal.

\section{INTRODUCTION}

Incorporation of proteins in a given food product requires the availability of specific information about their functional properties. The effect of food processing on the functional properties of proteins and protein products must be taken into account apart from their nutritional properties. Finch (1) stated that protein may be used in foods for their functional properties as well as their nutritive properties.

The value of cottonseed meal as a food depends not only on the nutritive value of the protein but also to a large extent on the amount of the gossypol present. The presence of gossypol is a limiting factor in the use of cottonseed meal for animal feed and human foods; gossypol in the free form has been found to be toxic to monogastric animals (2). The Protein Advisory Group of the U.N., limited the free gossypol content of cottonseed protein products not exceeding $0,06 \%$ in order to be used safely for monogastric animal feeding (3).

Cottonseed meal of high nutritional quality must have adequate levels of available lysine. Cottonseed protein products are known to be limiting in the amino acid lysine. Beside this limitation, gossypol combines with cottonseed protein and the reaction involves the free amino group of lysine (4).

It thus seems worthwhile to examine the effect of some degossypolisation techniques on the functional properties of cottonseed meal.

\section{EXPERIMENTAL}

\subsection{Preparation of samples.}

The cottonseed meal used throughout this study was prepared from decorticated ground seeds. The kernels were ground in a Wiley Mill and extracted several times with nhexane in a Waring blender, until the residual oil in the meal did not exceed $1 \%$. The defatted meal was desolventized by spreading in a hood for 24 hours at room temperature. The desolventized meal was then ground to pass an 80 mesh screen. All reagents used are of analytical grade.

\subsection{Methods of analysis.}

Nitrogen was determined by a semimicro kjeldahl proce- 
dure (5); and protein calculated as $N \times 6,25$. Samples that have been subjected to ammonium nitrate, ammonium hydroxide and ethanolamine treatments, these samples have been treated as in the micro kjeldahl procedure (without acid digestion treatments) to determine the nonprotein nitrogen which is then subtracted from the respective total nitrogen figures obtained by the usual micro kjeldahl procedure (with acid digestion). Nitrogen solubility was carried according to Lyman et al. procedure (5). Available lysine was determined by (7). Free and total gossypol determinations was carried according to the method of Pons et al. (8).

\section{Functional properties}

The bulk density, flowability and wettability were carried according to (14). Water absorption capacity was determined according to (15), and foam capacity and foam stability as recommended by (16).

\subsection{Degossypolisation treatments}

The defatted 80 mesh cottonseed meal was subjected to the following degossypolisation treatments:

\section{Modified alkaline peroxidation treatment}

The alkaline peroxidation treatment was carried according to Johnson and Anderson (9). Steaming was applied instead of heating paste resulting from the meal and sodium hydroxide on a water bath, before and after treatment with hydrogen peroxide.

\section{Acetic acid treatment}

Acetic acid is known to react with gossypol to form a gossypol-acetic acid complex which is more stable than gossypol itself. Using acetic acid as a reagent for degossypolising cottonseed meal was carried according to Pons et al. (10).

\section{Azeotropic treatment}

The work reported by Frampton et al. (11) (12) using acetone-hexane-water azeotrope proved to be quite superior as for as degossypolisation is concerned and in addition it gave a high quality protein. Azeotrope with some additives was also examined (13).

\section{a) Azeotrope without additives}

The meal was extracted with acetone:hexane:water in the ratio of 53:44:3 using a soxhlet apparatus.

\section{b) Azeotrope:acetic acid}

The meal was extracted with azeotrope:acetic acid mixture $(100: 3 \mathrm{v} / \mathrm{v})$. The residual acetic acid was removed by five extractions with $100 \mathrm{ml}$ each of ethanol.

\section{c) Azeotrope:ammonium nitrate}

The meal was extracted with azeotrope:ammonium nitrate $(100 \mathrm{ml}: 0,5 \mathrm{~g} \mathrm{v} / \mathrm{w})$ for 24 hours with occasional shaking. The meal was then filtered, re-extracted twice with $100 \mathrm{ml}$ portions of fresh azeotrope with no additive, and finally with anhydrous ether to remove last traces of azeotrope and additive.

\section{d) Azeotrope:ammonium hydroxide}

The meal was extracted with azeotrope:ammonium hydroxide (100:3 v/v) as in III C: The meal was then heated at $50^{\circ} \mathrm{C}$ for 2 hours to remove last traces of $\mathrm{NH}_{3}$.

\section{Ethanolamine treatment}

The meal was mixed with ethanolamine solution in the ratio of $(2: 1 \mathrm{w} / \mathrm{v})$. Ethanolamine solution being $(0,5 \mathrm{~g}$ ethanolamine in $100 \mathrm{ml}$ ethyl alcohol). The meal/ethanolamine mixture was digested in a porcelain basin covered with a watch glass for a period of $30 \mathrm{~min}$ on a boiling water bath. The solvent was then evaporated and extracted five times with $100 \mathrm{ml}$ portions of $\mathrm{n}$-hexane.

\section{RESULTS AND DISCUSSION}

Since gossypol is supposed to be responsible for certain toxic and antinutritional properties of cottonseed protein, it results in limiting the use of cottonseed protein products for human consumption. Treatments for the degossypolisation of cottonseed meal have been well established. In this work some of the treatments known to efficiently reduce the free gossypol content of cottonseed meal have been applied, and the functional properties of the degossypolised products investigated.

\subsection{Degossypolisation of cottonseed meal}

Table I gives the gossypol, protein and available lysine contents of the seven treated cottonseed meal, as well as the nitrogen solubility of the protein.

Treatment of cottonseed meal by the modified alkaline peroxidation method resulted in the reduction of total gossypol to a minor value of $0,07 \%$ all of it in the bound form. Although the value of free gossypol for this treated meal is zero, yet this treatment severely damaged the nitrogen solubility of the protein which decreased from $79.4 \%$ for the untreated cottonseed meal to $21,6 \%$ after treatment, and the available lysine decreased from 2,68 to 1,54 . 
Table I

Analysis of treated cotonseed meal

\begin{tabular}{|c|c|c|c|c|c|c|}
\hline \multirow[t]{2}{*}{ Treatment } & \multicolumn{3}{|c|}{ Gossypol (\%) } & \multicolumn{2}{|c|}{ Protein N-Sol } & \multirow{2}{*}{$\begin{array}{c}\text { Avail- } \\
\text { lys }\end{array}$} \\
\hline & $T$ & $\mathrm{~F}$ & B & $\%$ & $\%$ & \\
\hline $\begin{array}{l}\text { Untreated cottonseed } \\
\text { meal }\end{array}$ & 1.38 & 0.74 & 0.64 & 48.12 & 79.4 & 2.68 \\
\hline Mod. Alk. Peroxidase & 0.07 & 0.00 & 0.07 & 49.4 & 21.6 & 1.54 \\
\hline Acetic acid & 0.31 & 0.03 & 0.28 & 49.0 & 84.6 & 2.78 \\
\hline Azeotrope & 0.28 & 0.03 & 0.25 & 48.7 & 83.3 & 2.74 \\
\hline Azeot: acetic acid & 0.22 & 0.02 & 0.20 & 46.1 & 83.8 & 3.04 \\
\hline Azeot: Am nitrate & 0.27 & 0.05 & 0.22 & 47.3 & 81.3 & 2.44 \\
\hline Azeot: Am hyd. & 0.19 & 0.01 & 0.18 & 46.8 & 87.4 & 3.09 \\
\hline Ethanolamine & 0.08 & 0.03 & 0.05 & 45.7 & 81.7 & 2.69 \\
\hline
\end{tabular}

$\mathrm{T}$ : Total gossypol

F: Free gossypol

B: Bound gossypol

Acetic acid treatment resulted in slight improvement in the protein, available lysine, and nitrogen solubility of the treated cottonseed meal. This was accompanied with a considerable reduction in total, bound and free gossypol.

Azeotropic extraction of cottonseed meal resulted in slight increase in nitrogen solubility and available lysine, while the protein content was unchanged. The total bound and free gossypol content was considerably reduced after the treatment.

All azeotropic extractions with additives such as acetic acid, ammonium nitrate and ammonium hydroxide as well as the treatment of cottonseed meal with ethanolamine resulted in a slight decrease in the protein content of the treated meals. This was accompanied with slight increase in the nitrogen solubility, especially for the cottonseed meal treated with azeotrope:ammonium hydroxide mixture, which showed $10 \%$ increase in nitrogen solubility. Azeotropic extraction with ammonium nitrate resulted in reduction of available lysine, while ethanolamine treatment did not change the available lysine content. Azeotropic extraction with acetic acid and ammonium hydroxide resulted in $13,4 \%$ and $15,3 \%$ increase, respectively, in available lysine. The three azeotropic extractions with additives and ethanolamine treatment all reduced the free gossypol content to bellow the permissible level $0,06 \%$ (3), also the total and bound gossypol were significantly reduced.

Figure 1 shows that all seven treatments efficiently reduced the gossypol content of cottonseed meal. Reports indicate that cottonseed protein products meant for monogastric animal feeding are restricted to a free gossypol content not higher than $0,06 \%$. Highest free gossypol content reached $0,05 \%$ for the treatment with azeotrope:ammonium nitrate, while the modified alkaline peroxidase treatment reduced the free gossypol to zero. Although the seven treatments reduced the free gossypol to the permissible level for human consumption, yet considering the nitrogen solubility and available lysine contents, some treatments have to be excluded. The modified alkaline peroxidase treatment resulted in a free gossypol zero yet severly damaged the nitrogen solubility and available lysine, and the azeotrope:ammonium nitrate treatment resulted in reduction of available lysine.

Kadan et al. (17) (18) in an attempt to reduce the colour of protein isolates prepared from cottonseed, extracted liquid cyclone processed cottonseed protein with azeotropic

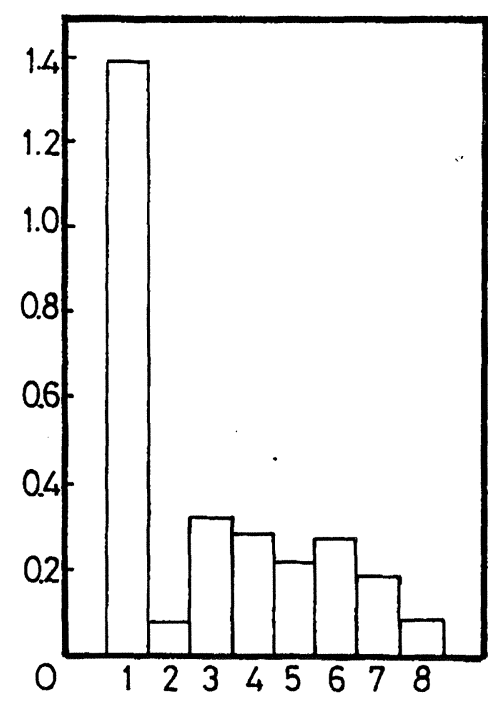

Total

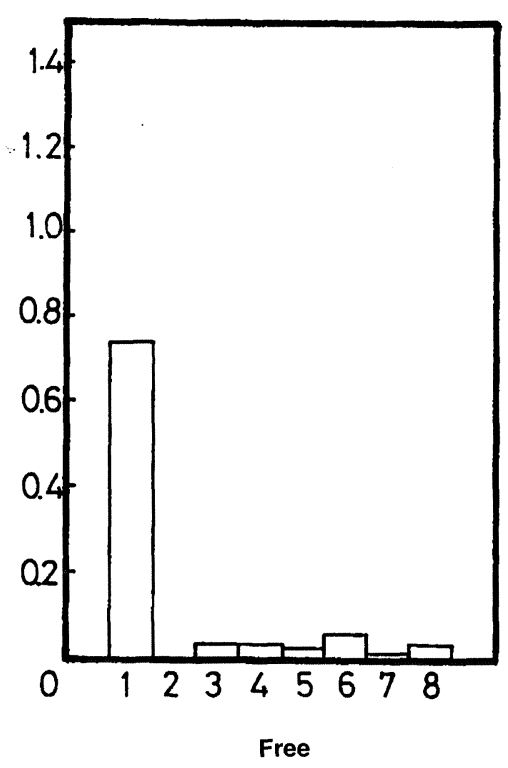

Fig 1.

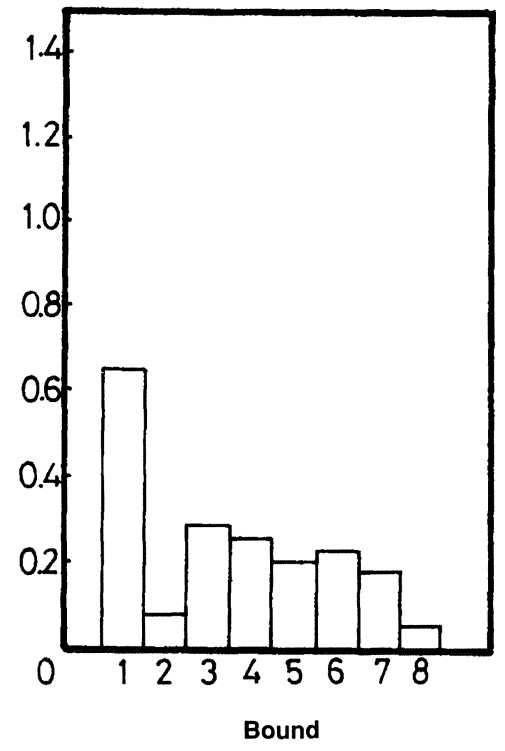

Bound

Effect of degossypolisation by different treatments on removal of gossypol
1. CSM
2. Alkal. peroxid
3. Acetic acid.

4. Azeotrope.
5. Azeot.: acetic acid.
6. Azeot.: amm. nitrate.
7. Azeot. amm. hyd

8. Ethanolamine 
Table II

Functional properties of treated cottonseed meal

\begin{tabular}{|c|c|c|c|c|c|c|}
\hline Treatment & Water absorption $\%$ & Flowability (Sec) & Foam Capacity (Sec) & Foam Stability (Sec) & Wettability & Bulkdensity $\left(\mathrm{g} / \mathrm{cm}^{3}\right)$ \\
\hline Untreated cottonseed meal & 320.4 & 11.37 & 62.0 & 10.0 & 6.0 & 0.67 \\
\hline 1. Alkaline peroxidase & 166.0 & 5.0 & 68.0 & 8.0 & 11.5 & 0.12 \\
\hline 2. Acetic acid & 377.15 & 5.0 & 56.0 & 6.0 & 2.15 & 0.18 \\
\hline 3. Azeotrope & 369.1 & 2.5 & 56.0 & 5.0 & 30.0 & 0.17 \\
\hline 4. Azeot: Acetic acid & $\because 323.3$ & 5.0 & 53.0 & 3.0 & 17.0 & 0.18 \\
\hline 5. Azeot: Amm. nitrate & 341.1 & 3.0 & 60.0 & 9.0 & 9.11 & 0.17 \\
\hline 6. Azeot: Amm. hydroxide & 322.5 & 2.0 & 54.0 & 5.0 & 11.1 & 0.16 \\
\hline 7. Ethanolamine & 316.0 & 2.5 & 55.0 & 6.0 & 7.11 & 0.16 \\
\hline
\end{tabular}

mixtures of hexane and 8 other solvents, and with a mixture containing polar and non polar solvents. They found that some solvents improved the colour of extracted flours but neither the colour of isolates made from these flours nor the resulting biscuits made from them were improved. Hensarhing and Jacks (19) extracted cottonseed with hexane and acidic hexane and compared the properties of the result and miscella and meal. Nutritional analysis of the extracted cottonseed meals indicated that protein efficiency ratios, digestibilities, -amino free lysine and free and total gossypol contents. Were essentially, identical with each type of solvent. Johson et al. (20) made pilot plant studies on extracting cottonseed with methylene chloride, this produced cottonseed meal that was suitable for use in poultry feeds because the gossypol was extracted especially when using a blend of $5 \%$ ethyl alcohol in methylene chloride.

\subsection{Functional properties of degossypolised} cottonseed meal

The incorporation of a given protein product in a given food product depends on its functional properties. Examples of products for special concern include bakery products, beverages, cereals, confections, dairy products, eggs, macaroni, processed meats, as well as speciality food and animal feeds. The functional roles of protein apart from nutrition, fall into the following categories: emulsification, water absorption, adhesion, gelation, suspension, dis persion, fibre and film formation, stabilization, fat binding and foamability, etc.

Table II gives the functional properties of the seven treated cottonseed meal samples.

Water absorption capacity is considered to be useful as an indication of performance in several food formulations especially some involving dough handling. Improvement in the water absorption capacity resulted from treatments with acetic acid, azeotrope and azeotrope with ammonium nitrate to reach $377,2 \%, 369,1 \%$ and $341,1 \%$, respectively, compared to $320,4 \%$ for untreated cottonseed meal, and $260 \%$ for soybean meal

Wettability is of special importance in the use of the product in instant food. The lower the wettability values the better. Best value 2,15 was attained with acetic acid treated cottonseed meal, compared to untreated cottonseed meal 11,37 and soybean meal 10,0 . Flowability is another crite- rion for the determination of instant property. It signifies the ability of a powder to flow. All seven treatments resulted in improvement of the flowability property of the resulting treated meal. Best results are achieved with azeotropic treatments with or without additives and ethanolamine.

Foam capacity and foam stability is a property desirable for whipped topping, whipped desserts, and frozen desserts among others. Results in table II show that all seven treatments resulted in treated meals with less foam capacity and foam stability than the untreated meal. Only a slight improvement in foam capacity for the modified alkaline peroxidation treated meal, but this treatment is not to be considered since it damages the nitrogen solubility and available lysine.

Bulk density is an important factor since it helps in choosing the appropriate packaging units. All treatments resulted in a considerable improvement in the bulk density of the treated meal.

\section{CONCLUSION}

The overall results recommends the use of acetic acid method for degossypolisation of cottonseed meal since it improves the nitrogen solubility and available lysine, reduces the free gossypol to $0,03 \%$, and improves the water absorption capacity, wettability and flowability. The protein product resulting from acetic acid treatment can be incorporated into bakery products and instant products. The same can be said the product resulting from azeotrope: ammonium hydroxide treatment. Ethanolamine treatment is recommended for the preparation of protein products for instant foods.

\section{REFERENCES}

1. Finch, R. (1970).-«Protein for human foods»--CRC Reviews in Food Technology 1, 519-520

2. El-Nockrashy, A.S.; Lyman, C.M. and Dollahite, J.W. (1963).-«The acute oral toxicity of cottonseed pigment glands and intraglandular pigments".-J. Am. Oil Chemists'Soc. 40, 14-17.

3. FAO/WHO/UNICEF (1964).-«Protein Advisory Group News Bull».-4, Aug.

4. Lyman, C.M.; Baliga, B.P. and Slay, M.W. (1959).-«Reactions of proteins with gossypol».-Arch. Biochem. Biophys. 84, 486-489.

5. Clark, E.P. (1943).-«Semimicro quantitative organic analysis».-Academic Press, New York. 
6. Lyman, C.M.; Chang, W.Y. and Couch, J.R. (1953).-«Evaluation of protein quality in cottonseed meals by chick growth and by a chemical index method".-J. Nutrition 49, 679-690.

7. Hurrel, R.F.; Lerman, P. and Carpenter, K.J. (1976).-«Reactive lysine in food stuffs as measured by a rapid dye-binding procedure».-J. Food Sci. 44, 1221.

8. Pons, W.A. Jr.; Pittman, R.A. and Hoffpauir, C.L. (1958).-«3-Amino-1propanol as a complexing agent in the determination of total gossypol’.-J. Am. Oil Chemists'Soc. 35, 93-97.

9. Johnson, R.A. and Anderson, P.T. (1963).-«Detoxification of gossypol containing seeds or press cakes".-Patente U.S. № 3.084 .046 .

10. Pons, W.A. Jr.; Pominiski, J.; King, W.H.; Harris, J.A. and Hopper, T.H. (1959).-«Recovery of gossypol from cottonseed gums».-J. Am. Oil Chemists'Soc. 36, 328-332.

11. Mann, G.E.; Carter, F.L.; Frampton, V.L.; Watts, A.B. and Johnson, C. (1962).- «Evaluation of cottonseed meals prepared by extraction with acetone - hexane - water mixtures".-J. Am. Oil Chemists'Soc. 39, 3690.

12. King, W.H.; Kuck, J.C. and Frampton, V.L. (1961).-«Properties of cottonseed meals prepared with acetone pet. ether-water azeotrope".J. Am. Oil Chemists'Soc. 38, 19-21.

13. Faid, S. (1964).-«Degossypolisation and chemical evaluation of egyptian cottonseed".-Ph. D. Thesis, Faculty of Science Cairo University.

14. Lucas Meyer GmbH and Co. (1982).-Instantizing with Metarin Publication, p. 13-14.

15. «Soybeans, chemistry and technology» en «Proteins» Vol. 1 (1978), p. 452-456.-Smith, A.K. and Circle, S.J. (Ed.).-The AVI Publishing Co. Inc., Westport. (Conn).

16. A.O.A.C.-«Official methods of analysis».-10th Ed.-J. Assoc. Offic. Agric. Chemists', Washington D.C., 148

17. Kadan, R.S.; Ziegler, G.M. Jr. and Spadaro, J.J. (1978).-Cereal Chem. $55,919$.

18. Hensarling, T.P. and Jacks, T.J. (1982).-«Acidic hexane extraction of oilseeds: product quality".-J. Am. Oil Chemists'Soc. 59, 516-518.

19. Hensarling, T.P. and Jacks, T.J. (1983).-«Solvent extraction of lipids from soybeans with acidic hexane".-J. Am. Oil Chemists'Soc. 60, 783784 .

20. Johnson, L.A.; Farnsworth, J.T.; Sadek, N.Z.; Chamkasen, N.; Lusas, E.W. and Reid, B.L. (1986).-«Pilot plant studies on extracting cottonseed with methylene chloride».-J. Am. Oil Chemists'Soc. 63, 647-652.

(Recibido: Abril 1993) 